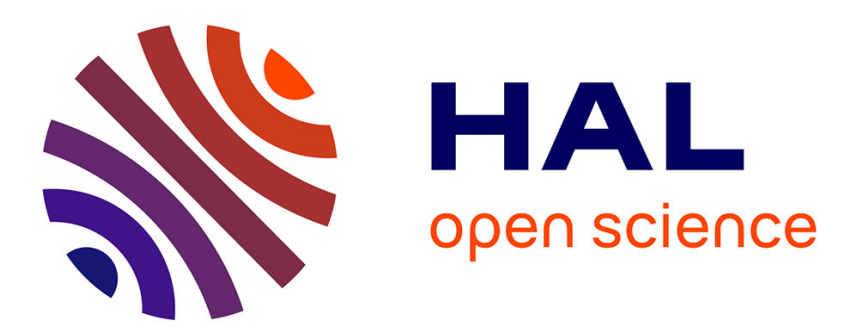

\title{
Historical Study of Chambord Castle: Basis for Establishing the Monument Health Record
}

Sarah Janvier-Badosa, Kévin Beck, Xavier Brunetaud, Muzahim Al-Mukhtar

\section{To cite this version:}

Sarah Janvier-Badosa, Kévin Beck, Xavier Brunetaud, Muzahim Al-Mukhtar. Historical Study of Chambord Castle: Basis for Establishing the Monument Health Record. International Journal of Architectural Heritage, 2013, 7 (3), pp.247-260. 10.1080/15583058.2011.634959 . hal-02090617

\section{HAL Id: hal-02090617 https://hal.univ-lorraine.fr/hal-02090617}

Submitted on 4 Apr 2019

HAL is a multi-disciplinary open access archive for the deposit and dissemination of scientific research documents, whether they are published or not. The documents may come from teaching and research institutions in France or abroad, or from public or private research centers.
L'archive ouverte pluridisciplinaire HAL, est destinée au dépôt et à la diffusion de documents scientifiques de niveau recherche, publiés ou non, émanant des établissements d'enseignement et de recherche français ou étrangers, des laboratoires publics ou privés. 


\title{
A historical study of Chambord castle: A basis for establishing the health record of the monument
}

\author{
Sarah Janvier-Badosa, Kévin Beck, Xavier Brunetaud, Muzahim Al-Mukhtar
}

Centre de Recherche sur la Matière Divisée UMR 6619, 1B rue de la Férollerie, 45071 Orléans Cedex 2, France

\begin{abstract}
:
The conservation of built heritage requires a good knowledge of the materials and the history of the monument in question. One objective of the SACRE ${ }^{1}$ project is to establish the health record of a monument. Chambord castle was built out of tuffeau limestone in 1519. This limestone, which comes from the Loire Valley, is extremely fragile, causing spalling and exfoliation to occur on the surface of the stone. Two parts of the castle are studied in this paper: the south façade, entrance to the castle, and the east tower. The mapping of the different origins and dates of the stones forms the basis of the health record of the castle. The comparison between this mapping and the location of damages on the façades shows different type and degree of degradation concerning tuffeau. The topography and the orientation of the building are also significant parameters that contribute to the development of specific types of degradation.
\end{abstract}

Keywords: Chambord castle; historical data; limestone; tuffeau; degradation; restoration

\section{Introduction}

The Loire Valley, known for its numerous castles built over the centuries, is classified as a World Heritage site by UNESCO since 2000. The conservation of this heritage site is a cultural duty and a multidisciplinary scientific subject.

The study presented in this paper is part of a research programme concerning the management of restoration of heritage sites. The focus of SACRE project is to establish "Monument Identity and Health Record" (MIHR). MIHR is a tool that collects historical data regarding the construction of Chambord castle, its subsequent restorations and its current state of alteration, in order to propose a schedule for future restorations.

The tuffeau, main stone used for the construction of the Chambord castle, is a soft limestone with a high porosity of about 45\% (Dessandier, 1995; Beck et al. 2003). Different types of deterioration, mainly granular disintegration and spalling, are observed on monuments built with tuffeau (Philippon, 1992; Rautureau, 2001; Beck, 2003; Beck, 2005). This stone is very fragile, sensitive to climate variations and can quickly degrade, sometimes a few decades after the laying of the stone on the monument. The MIHR allows the monitoring of the health and the healthcare of the monument in order to plan the restoration. Until now, the restorations were often made in emergency, with a focus on risk areas and areas more accessible, generally for aesthetic reasons.

This paper aims to describe the history of stones used in the construction of Chambord castle mainly two sections dating from the first part of the $16^{\text {th }}$ century: the south façade and the east tower (figure 1). The various type of degradations are then analysed considering the history of stones (implementation, restoration or replacement) and their location on the monument. The tower is located at the east of the castle, but the studied façade, is directed to the southeast, and commonly called "south façade". This façade, is the main entrance of the castle, was often modified by the various kings and owners, and often restored. The south façade is interesting to study because dates and provenances of replacements are various. The east tower was less valued and little restored. The stones of the tower are original, highly degraded and so of a great interest to this study, which aims to link types of stones, ages of stones and state of degradation and orientations and climatic conditions.

It is difficult to find authentic sources of information regarding the ancient materials used and the different stages of the restoration of historical monuments such as Chambord castle. However, the recording, stone by stone, of the different rocks used and the different replacements carried out during different stages of restoration is the starting point for the study of alterations of the stones of the castle. These data are the basis for the development of the monument identity and the health record of the monument.

\footnotetext{
${ }^{1}$ Suivi des Altérations, Conservation et Restauration des monuments en pierres calcaires Degradation monitoring, characterization and restoration of limestone monuments
} 

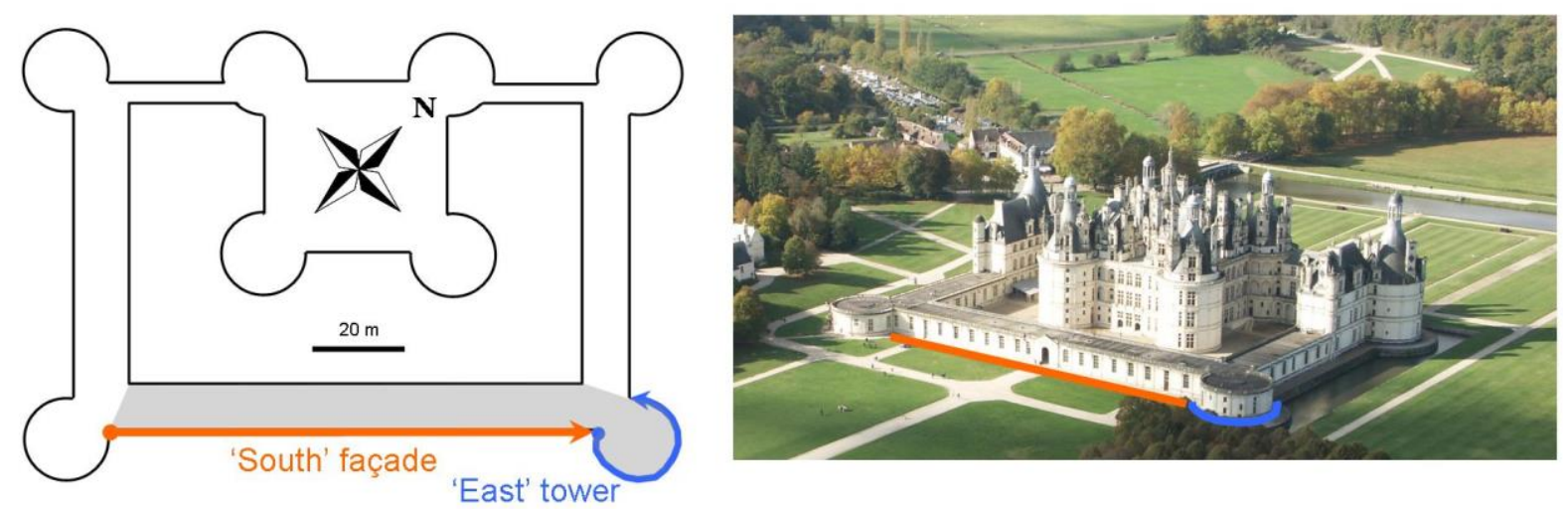

Fig. 1: The low surrounding building with the south façade and the east tower of Chambord castle

\section{The study of archives}

\subsection{A bibliographical, iconographic and archaeological study of the castle of Chambord}

Written documents concerning Chambord castle are rare. In spite of its world-wide reputation, Chambord remains an unsung building. Most of the archives relating to the construction of the castle disappeared during the transfer of archives from Blois to Paris in the $18^{\text {th }}$ century. Therefore, many of these documents were destroyed or dispersed among private collections, and elements relating to the construction, the initial projects, and the exact name of one or several architects remain incomplete (Martin-Dumézil, 1986).

In addition to texts relating to the history of the construction of the monument, reports of its restoration have been kept since the $19^{\text {th }}$ century ${ }^{2}$. These documents mention the maintenance of the castle, the village and the walls of the park (masonry work, framework, glasswork, painting, locksmiths, etc). They are interesting, as they allow us to complete our knowledge of the reorganisation or restoration of various parts of the castle.

Furthermore, these reports of the restoration process are very often completed by plans and drawings of elevations, which can be very useful. However, these documents are to be used with caution, because they are often subjective. Old photographs also provide valuable points of reference regarding the construction and restoration processes.

Archaeology also provides important data. Many stones in Chambord castle show lapidary signs (Fig. 2). Often, each stone cutter engraved his own distinctive sign into the stones he sculpted. For plain vertical walls, workers were paid by the "toise" (area), or by the day. For carved sections (such as cornices, pilasters, mouldings and capitals), they were paid according to the task (e.g. the number of sculptures). On all these value added stones, lapidary signs were observed (Châtenet, 2001). These marks give guidance regarding the chronology of the works and the organisation of the construction process. They also allow us to identify stones dating from earlier stages of the building process. For the identification of the generic stone used in the façades, in addition to lapidary signs, archives provide important information, although it is sometimes incomplete.

\footnotetext{
2 Departmental Archives of Loir-et-Cher, Blois (41), 37 Q

Departmental Archives of Loiret, Orléans (45)

Médiathèque de l'Architecture et du Patrimoine, Charenton-le-Pont (94)

Direction Régionale des Affaires culturelles (DRAC) of Région Centre, Orléans (45)
} 


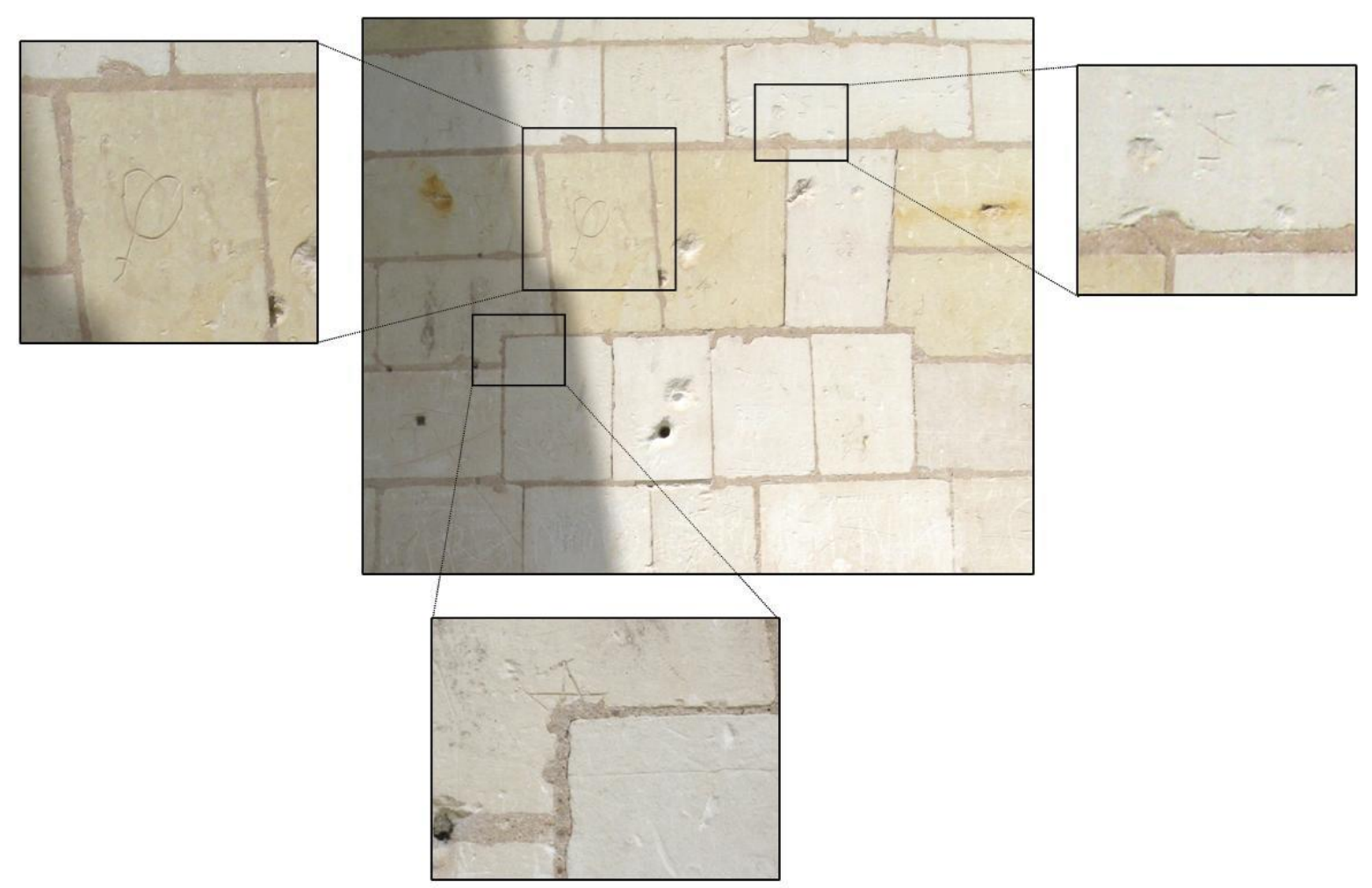

Fig. 2: South façade: door walled on the first left span, with a lapidary sign cut by the addition of a stone to the wall above the door, probably before 1555

\subsection{History and construction materials of the castle of Chambord}

The site of Chambord is in the middle of the forest, alongside the River Cosson, which is a tributary of the Beuvron, which is itself a tributary of the Loire. Gallic housing, then a medieval castle built by the Counts of Blois, existed on the site before the construction of Chambord castle in 1519 by François I, the King of France.

For the construction of Chambord castle, members of the first team of stonemasons were appointed in 1519. Shortly after the departure of François I to Italy (1525), where he was held captive, work was stopped for 27 months between July 1524 and October 1526. Then, a new team was appointed, which was gradually replaced between 1538 and 1555. At this time, the structural work seems to have stopped without being finished but, available documents are incomplete to provide precise information on the progress of the work during each period. However, documents assume that after the development of the foundations, the construction process started in the dungeon, and was then extended to the low and enclosing buildings, which were partially completed at the time of the death of François I in 1547 (Châtenet, 2001).

Historically, tuffeau material is used for the construction of Chambord, due to its geographical proximity. The tuffeau of Bourré (see location in Fig. 3) is the dominant stone in the castle, in $16^{\text {th }}$ century works. Texts say that tuffeau limestone used during the reign of Francois I for the construction came from six different quarries and were used to an equal extent without attention being paid to their strengths or physical characteristics (Penet, 1963). 


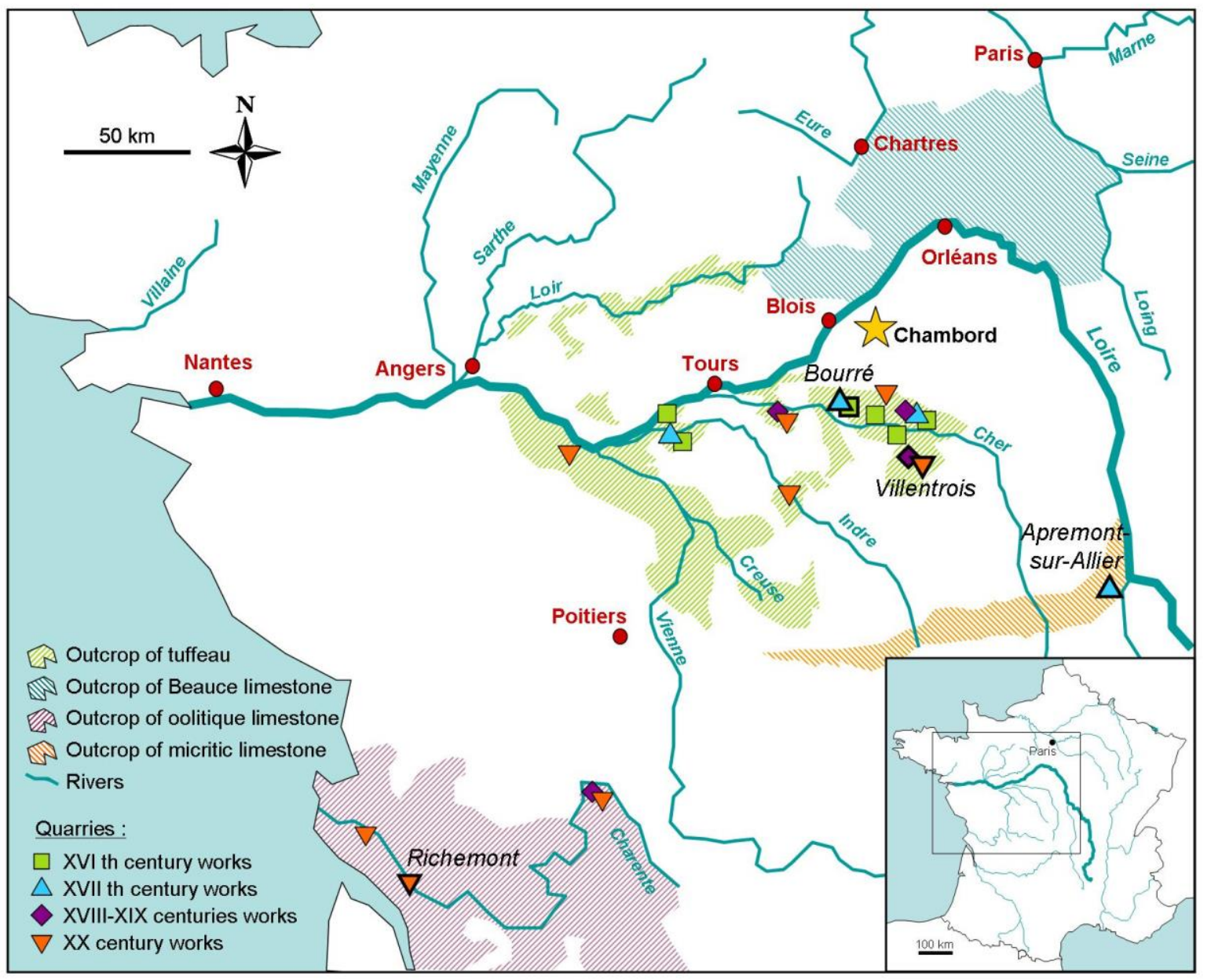

Fig. 3: Simplified map of the location of quarries used to the construction of the castle of Chambord (from Mussat, 1991; Rautureau, 2001; Yvard, 1976; Gorget, 1990)

The tuffeau which was also used in the construction of the Loire valley castles is a soft limestone of Turonian age (from the Upper Cretaceous period, about 88 to 92 million years ago). In Latin, tofus means "spongy rock". This indicates the main characteristics of this rock: high porosity and permeability (table 1). Due to these characteristics, this material is sensitive to variations in humidity, rain or water infiltrations. Tuffeau may be white, grey or pale yellow. It is composed of several minerals: quartz, calcite, amorphous silica and clay minerals, which vary in terms of proportion from one rock to another. The chemical composition, physical characteristics and colour of the stone varies from one deposit to another (Beck et al., 2003).

\begin{tabular}{|c|c|c|c|c|}
\hline & Tuffeau & Richemont limestone & Beauce limestone & $\begin{array}{l}\text { Apremont-sur-Allier } \\
\text { limestone }\end{array}$ \\
\hline Geological age & Turonian & Bajocian & Oligocene & Bajocian \\
\hline Color & $\begin{array}{l}\text { White - light beige } \\
\text { (dry) } \\
\text { Greenish (saturated) }\end{array}$ & $\begin{array}{l}\text { Light beige (dry) } \\
\text { Reddish (saturated) }\end{array}$ & White-grey & White - light beige \\
\hline $\begin{array}{l}\text { Mineralogical } \\
\text { Composition }\end{array}$ & $\begin{array}{l}\text { Siliceous limestone } \\
\text { calcite }(50 \%) \\
\text { opal }(30 \%), \\
\text { quartz }(10 \%), \\
\text { clayey minerals } \\
(10 \%)\end{array}$ & $\begin{array}{l}\text { Oolitic limestone } \\
\text { calcite }(97 \%), \\
\text { quartz }(1 \%), \\
\text { clayey minerals }(2 \%)\end{array}$ & $\begin{array}{l}\text { Lake limestone } \\
\text { Calcite (95\%) } \\
\text { Quartz (5\%) }\end{array}$ & $\begin{array}{l}\text { Micritic limestone } \\
\text { calcite }(75 \%), \\
\text { quartz }(25 \%),\end{array}$ \\
\hline $\begin{array}{l}\text { Unconfined } \\
\text { compressive }\end{array}$ & $10 \mathrm{MPa}$ & $15 \mathrm{MPa}$ & $80 \mathrm{MPa}$ & $25 \mathrm{MPa}$ \\
\hline
\end{tabular}




\begin{tabular}{|l|l|l|l|l|}
\hline strength & & & & \\
\hline Bulk density & 1.3 & 2.0 & 2.5 & 2.1 \\
\hline Porosity & $45 \%$ & $25 \%$ & $10 \%$ & $20 \%$ \\
\hline Permeability & $10^{-13} \mathrm{~m}^{2}$ & $10^{-14} \mathrm{~m}^{2}$ & n/a. & n/a. \\
\hline
\end{tabular}

Table 1: Main properties of tuffeau (Beck et al., 2003), Richemont limestone (Birginie et al., 2000; Dessandier, 2000), Beauce limestone (Yvard, 1976), and Apremont-sur-Allier limestone (Gorget, 1990; Lorenz, 1991)

Quarries are usually located close to rivers in order to facilitate the transport of materials over long distances. Quarries which were used for these important construction sites have often been closed for centuries, and then new ones are opened for new works (Fig. 3). Therefore, it is difficult to locate quarries that are no longer in use (Mussat, 1991). The stone blocks used to build Chambord castle arrived at the port of Saint-Dyésur-Loire, which is five kilometres from the castle. They were cut on site as needed, as seems to be confirmed by the many piles of waste tuffeau found in the castle's courtyard during excavations in 1996 (Châtenet, 2001).

The extreme fragility of tuffeau has been well known since the Middle Ages. As a consequence, it was necessary to build the foundations with a harder stone. At Chambord, the foundations were built with lake limestone, called Beauce limestone. It is a more compact siliceous limestone with fine grains and a very small porosity (table 1). This limestone is mainly located between Orléans - Chartre and Paris Loire (Fig. 3). In this paper, only the tuffeau used in the elevation of the walls is studied.

Most of the subsequent kings did not care about the castle. Nevertheless, Louis XIV admired it a great deal, and after 1684, he reorganised the castle, and finished parts of the previously neglected building. New quarries of tuffeau have been opened for these works. Indeed, later texts have allowed us to identify three new quarries of tuffeau, which were opened for the works of Jules Hardouin-Mansart, architect, in the late 17th century (Martin-Dumézil, 1986). Archives showed that for the first time other limestone has been sometimes used in the castle: Apremont-sur-Allier limestone ${ }^{3}$. This micritic limestone, whose quarry is located upstream of Orleans, along the Loire (Fig. 3) is more resistant and less porous than tuffeau (table 1), Apremont-sur-Allier limestone was commonly used for the construction and the restoration in the $17^{\text {th }}$ century, around and in the south of Orleans (Gorget, 1990).

Afterwards, the castle was not maintained as fully as it could have been. During the French Revolution, it became a national property, and was bought and sold several times before being classified as a Historic Monument in 1840, and then acquired by the State (France) in 1930 (Châtenet, 2001). In 1981, Chambord castle was classified by UNESCO as a world heritage site, and then integrated into the group "Val de Loire" in 2000. Finally, it became an EPIC in $2005^{4}$.

Over the centuries, new tuffeau quarries are used as well as other harder limestones, more distant from the Loire. To replace tuffeau, oolithic limestone of Poitou-Charente has been much used from the 20th century (Fig. 3). So, in the early twentieth century, tuffeau quarries exploited are totally different from original tuffeau quarries. During the restoration of monuments, in the case of replacement stones, the question arises about the compatibility of these stones. Thus, in our example, for the South façade and the East tower, in the early twentieth century, the choice was to use only Richemont stone in substitution of tuffeau. At that time, many other tuffeau buildings were restored in Richemont stone, which is a white calcareous stone and considered more sustainable than tuffeau (Birginie, 2000; Dessandier, 2000). Richemont, limestone from quarries in Charente-Maritime, has the same geological age as tuffeau but with different properties from tuffeau (table 1). In the 90s, letters of architects and curators found in archives, show that considerations and guidelines of restoration are changing: Richmond stone is only used to make the transition between bases with hard limestone (Beauce limestone) and tuffeau facings. Finally, now, only Villentrois tuffeau is recommended by architects because it is considered similar to the original tuffeau: Bourré tuffeau ${ }^{5}$, very white tuffeaux, with fine grains (table 1), Quarries of Bourré no longer exist but the extraction of Villentrois tuffeau is near the old quarries of Bourré (Fig. 3).

\footnotetext{
${ }^{3}$ Departmental Archives of Loir-et-Cher, Blois (41), minutier Chambord 35E338

${ }^{4}$ Public, Industrial and Commercial Establishment

${ }^{5}$ Departmental Archives of Loir-et-Cher, Blois (41), Documents of Robert-Houdin, 127 J 47
} 


\section{Spatial distribution and age of the materials used in the south façade and in the east tower \\ 3.1. Methodology}

The façade and the tower of a height of about $8 \mathrm{~m}$ were photographed. The photos were assembled to form a frieze. With archive data and data collected in situ, the stone replacements of the different façades have now been precisely located. In this way, the south façade and the east tower have been carefully mapped. However, the results obtained should be used with caution because:

- archives (sources) are not significant enough to always determine the exact dating of rocks and their replacements;

- restoration does not exclusively involve substitution by new stones. Indeed, if the old stones removed from their location are relatively well preserved, they can be resized and replaced in another location. In addition, the weathered stones are not always replaced, but sometimes just renovated by surface treatment (cutting or abrasion of surface stones). According to literature sources, this was not the case for the south façade and the east tower observed in this study.

\subsection{The south façade}

Stones including lapidary signs on the south façade probably date back from the first stages of construction. Moreover, during the final phases of construction (between 1540 and 1545), interior transformations took place in the south façade (Bryant et al., 2007), perhaps leading to the walling of nine small doors, which are still visible in front and detectable by their lintels (Fig. 2).

Based on lapidary signs, various stones from the south façade can be considered to be original, according to their dating (Fig. 4). In fact, from 1683, under Louis XIV, the Royal Portal and the adjacent span were completely rebuilt ${ }^{6}$. Also during this time, the southern parts of the castle, which were originally covered with terraces, were covered with a mansard roof (Paquet, 1937), windows were enlarged and parts above the windows were cut $^{7}$. In this case, restoration seems to have involved cutting the existing stones, rather than replacing them. In 1937, a mansard roof was demolished and the cornices were restored. Stones were added above the windows in order to restore them to their original form. For these restorations, texts mentioned the use of "Salamander stones" from quarries of Saint-Même, in Charente. This stone has similar characteristics to those of Richemont stone, whose quarries are near (Fig. 3). This upper parts of the façade have been restored in 1856 or 1962 (sources are incomplete and we can not be sure) ${ }^{8}$.

In 1953, when the castle began to become a tourist destination, the reception desk was constructed. Stones under and around certain windows, on the right hand side of the south façade, were replaced on this occasion with Richemont limestone ${ }^{9}$. Finally, in 1962, the Royal Portal, which was badly damaged after the Second World War, was completely rebuilt, also with Richemont stone. The stylobate and numerous stones from the cornices also appear to have been restored with the same stones ${ }^{10}$. Quotations dating from 1856, and others dating from 1962, mention the replacement of these stones. However, the existence of quotations does not prove that the work was certainly done. Finally, since 1962, no more restorations have been carried out on the south façade.

\footnotetext{
${ }^{6}$ Departmental Archives of Loir-et-Cher (41), notarial act, 35 E 338, 12/05/1681

7 DRAC - CRMH, documents Chambord T10, 1994

${ }^{8}$ Médiathèque de l'Architecture et du Patrimoine, 0081/041/0115/07

${ }^{9}$ Médiathèque de l'Architecture et du Patrimoine, 0081/041/0115/15

${ }^{10}$ Médiathèque de l'Architecture et du Patrimoine, 0081/041/0115/25 et 0081/041/0115/26
} 


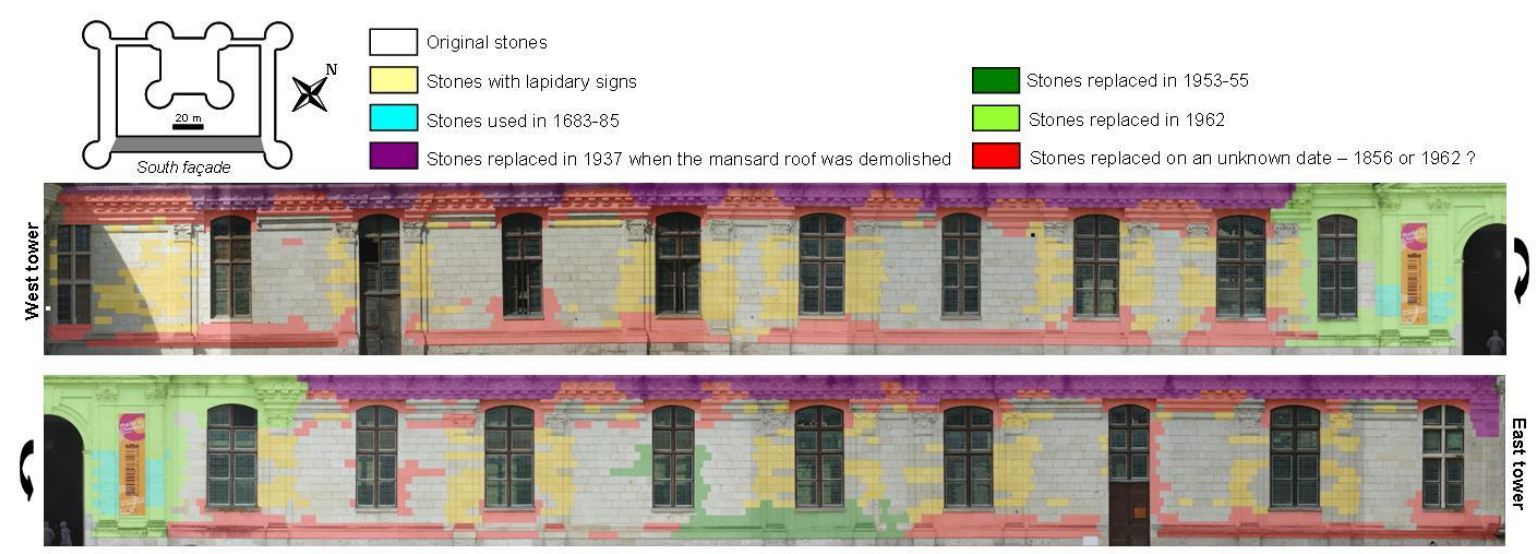

Fig. 4: Distribution of various stone replacements on the south façade

\subsection{The east tower}

Unlike the south façade, the east tower underwent only a few rearrangements (Fig. 5). As for the south façade, stones with lapidary signs can be considered to date from the early phases of construction. The first mentions in the reports of stones being replaced date from 1937, when the floor under a mansard roof which had been established on all of the low surrounding buildings was destroyed and replaced by the original terraces. At that time, the upper parts of the tower were restored using salamander stones ${ }^{11}$. Thereafter, guidelines of architects are to use stones close to the original: the Villentrois tuffeau is chosen. This tuffeau was used to make the fifth window from the left of the tower, it can be reliably dated from $1986^{12}$. The stylobate stones in the first four spans of the tower, which are accessible to the public, were replaced between $1994^{13}$ and $1999^{14}$ with Richemont limestone and tuffeau from Villentrois. Spans not accessible to visitors are non restored for financial reasons. Window frame no. 2 was also replaced with tuffeau. Finally, on the last spans of the frieze, adjacent to the eastern façade, some new stones were added, which were probably Villentrois stones. The dates at which they were replaced can be estimated as being between 1970 and $1980^{15}$. This mapping shows that the stones were mainly replaced in the upper parts. These parts were the most degraded because they are in relief, and therefore stones are more exposed. The salient stylobate, now very impaired, was previously partially restored. Probably, during the next restoration of the east tower, the stylobate will be restored first.

\footnotetext{
${ }^{11}$ Médiathèque de l'Architecture et du Patrimoine, 0081/041/0115/07, 1938

12 Departmental Archives of Loiret (45) documents of DRAC 1339 W 572

${ }^{13}$ DRAC - CRMH, documents Chambord T5, 1994

14 DRAC - CRMH, documents Chambord T10, 1999

${ }^{15}$ Departmental Archives of Loiret (45) documents of DRAC 1339 W 571, 1977, 1979, 1980
} 

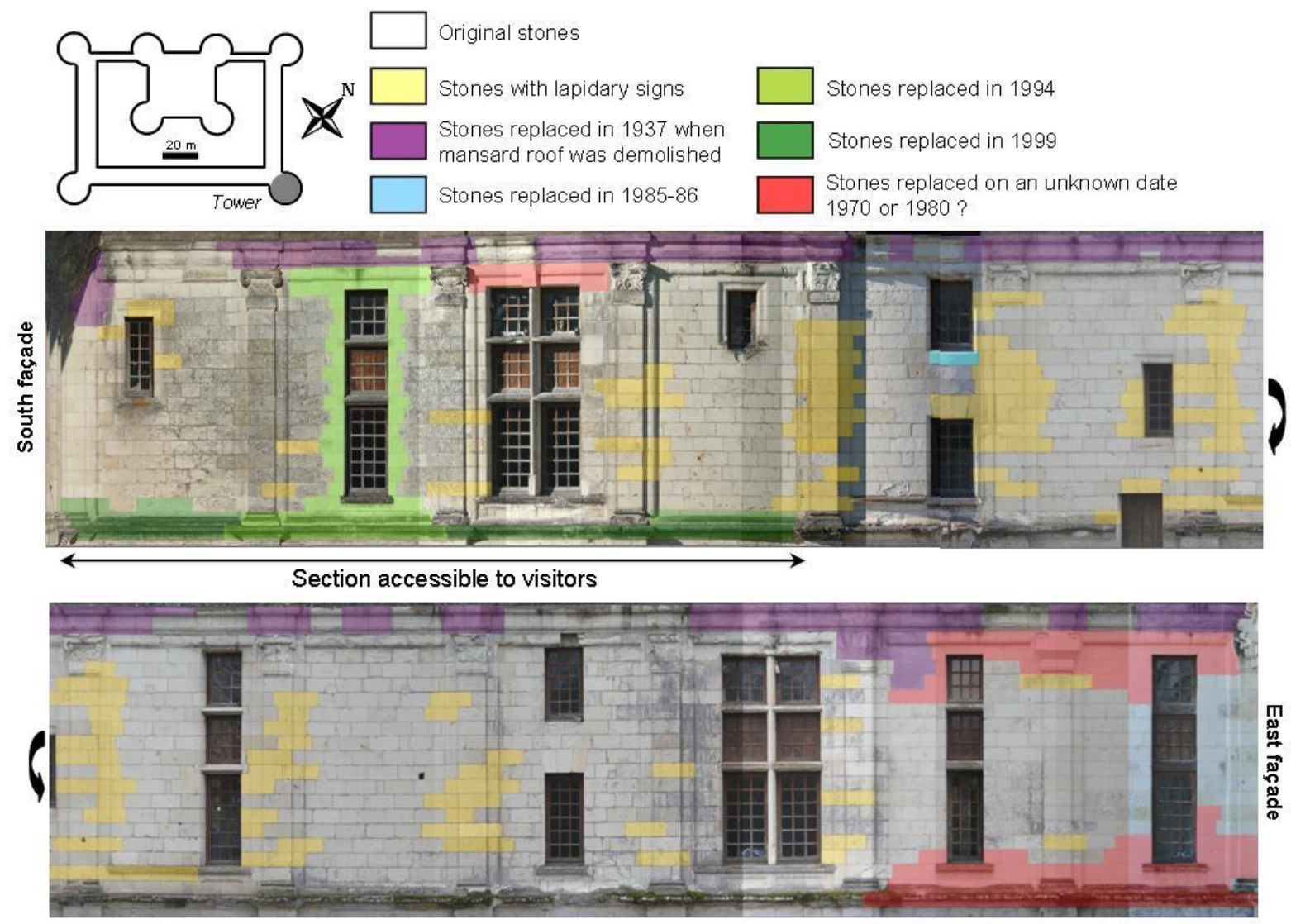

Fig. 5: Distribution of various stones replacements in façades of the east tower

\subsection{Synthesis of the study of archives}

The stones on the façades which have no colour code on the map can be considered as original stones (Fig. 4 and 5). The proportion of visible stones replaced during each period of restoration has been estimated using data from planar projection surfaces. These estimations cannot provide information regarding the volume of stones used. Moreover, these data should be treated with caution, as some dates for replacement may not be precise. However, this estimation gives the percentage of original visible stones ( $16^{\text {th }}$ century), compared to the percentage of stones replaced later on. It indicates that nearly $50 \%$ of stones on the south façade have been replaced. This proportion differs from the east tower, where $80 \%$ of the stones are original. As the main entrance for public visitors to the castle is in the south façade, this façade has therefore been largely restored over the centuries, unlike the east tower, which is further back and away from tourist traffic. Moreover, the east tower has degraded to a greater extent than the south façade due to its location, as it overlooks the River Cosson, and is exposed to the wind.

\section{Distribution of decay features}

\subsection{State of degradation}

The terminology and classification of the deterioration of stone have been defined in a glossary published by ICOMOS (2008). Five main categories of alteration are listed: cracks and deformations, features induced by material loss, discolorations and deposits, biological colonisation and detachments. The latter two categories are the most frequently observed alterations in tuffeau, and particularly in Chambord castle (Beck and Al-Mukhtar, 2005). Figure 6 shows the presence of various biological colonisations, such as mosses or lichens. The development of these degradations depends on various factors: the location and the orientation of the stones on the building, and the environmental conditions (temperature, relative humidity, rainfall, wind etc). The tower is covered with biological alterations. Indeed, mosses grow preferentially on protruding parts such as stylobate or window sills, in the shadier parts and thus the wettest of the tower (north). Different types of lichens, cover the stone facings and mortar joints. It should be noted that five center spans almost do not have this type of alteration. This part of the tower, toward south, is the most exposed to wind and also the most exposed to light. Perhaps the weather conditions are not favorable to the development of lichens (lichen grows 
better, protected from light) or a continuous erosion of stone by the wind occurs on this part of the tower (Philippon, 1992). Similary, on the south façade, all spans are oriented toward south. There are no lichens on the vertical walls. However, cornices and horizontal parts are covered with lichens.

The detachment of stones with different thicknesses resulting in spalling or exfoliation can also be observed in the figure 6. Spalling is the most common form of degradation in the case of tuffeau, and the most damaging. It concerns carved stones, but also vertical facings, often initiated by reliefs (pilaster, windows). Over time, a plaque (one to three centimetres thicknesses) gradually forms on the surface of stone, and pells. The resulting stone surface turns into powder. The physico-chemical mechanism behind the formation of such plaque is still unclear, and many hypotheses have been advanced (Philippon, 1992; Dessandier, 1995; ImbaultBrunet, 1999; Rautureau, 2001; Thomachot, 2002; Beck, 2006). Testing samples have been taken on damaged areas of the castle of Chambord. The result of mineralogical characterization reveals physico-chemical degradation with presence of gypsum content in the powder zone on both sides of the cracking zone. Exfoliation mainly occurs in carved stones, which have a high specific surface area and thus a greater surface for evaporation. They also affect the lower parts of stylobate or cornices, which are generally more sheltered from the rain, and thus from leaching (ICOMOS-ISCS, 2008). The analysis showed the presence of gypsum in the leaves of exfoliations. The process of formation of these alterations and the origin of gypsum (air pollution, restoration mortars...) is not yet defined.

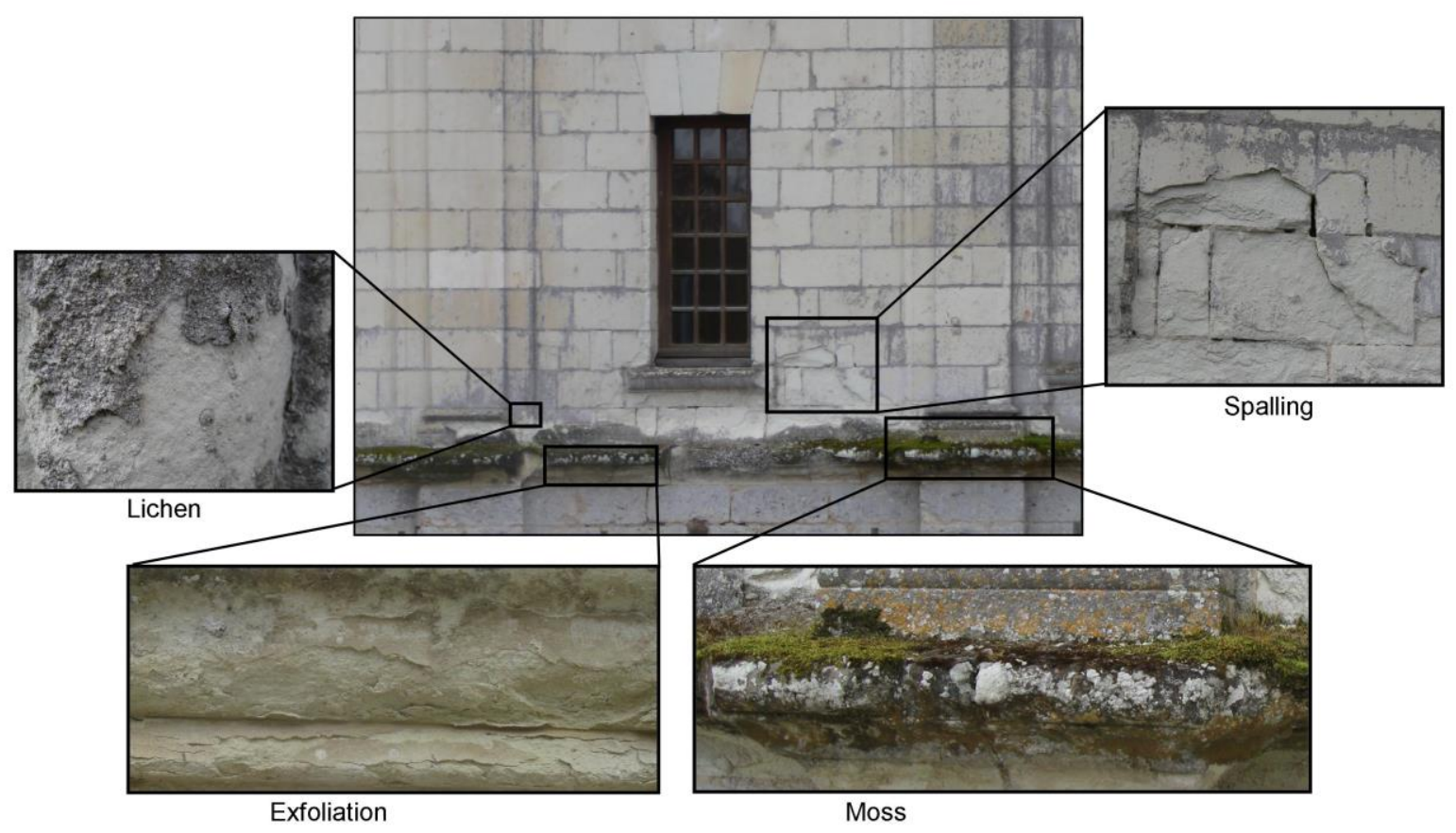

Fig. 6: Different types of alterations observed at Chambord - Example of the north part of the east tower

\subsection{Age, provenance and decay features of stones}

The façades have been mapped in order to locate decay changes and to find any correlations with the historical study of stones or other factors such as environmental conditions or the interior layout of the building.

The east tower was less restored and more exposed to climatic variations than the south façade. So, the tower is more degraded. Figure 7 shows that physicochemical degradations affected the oldest tuffeau (red zone), but not yet stones replaced in the $20^{\text {th }}$ century, tuffeau (squared zone) or Richemont stone (striped zone), because physicochemical degradations are a long process, conversely to biological degradations. Indeed, there is no observable relationship between biological alterations (green zone) and the age or provenance of the stone. The relief, the disposition and the orientation of the stones determine the location of biological alterations: a cornice with a horizontal relief is usually more covered with moss (because of water accumulation) than a vertical face (which dries quickly). So, vertical walls are colonized less rapidly than horizontal areas, as shown on the second bay of the tower. 


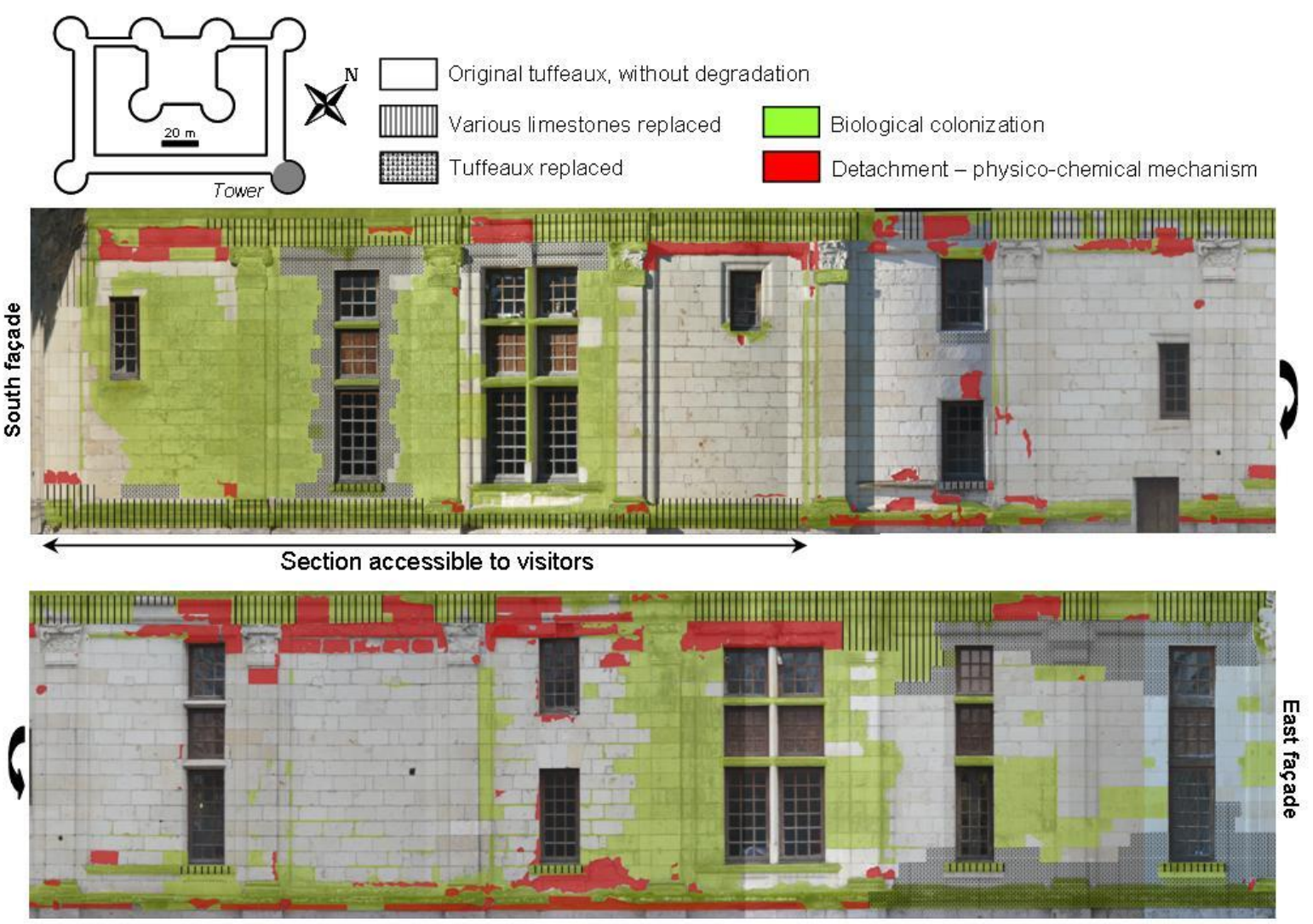

Fig. 7: Age and decay features of stones in the east tower

But, the portion of the building which faces north, in the shade or close to the rivers, presents a high concentration of lichens. Therefore, some stones, tuffeau or other limestones which have been recently replaced (twentieth century in general, and even 30 years) are entirely covered with biological degradations (green zone with superimposition of striped or squared zone). Indeed, with favorable weather conditions, the biological alterations can develop very quickly and even cover stones recently replaced.

Biological colonisations are dominant on these façades. However, they are not involved in the process of spalling or exfoliation, which are the phenomena in which we are most interested in this study. Indeed, biological colonizations are superficial and often unsightly, but may play a protective role by tempering the water exchange between the stone and its surroundings. Among all of the types of alterations observed on Chambord castle, the detachment of material is the most important degradation, and can cause security issues in addition to unaesthetic effect.

In the case of this detachment of material, the state of degradation may not be easily linked to the orientation or the position of the stone on the building. The southern part of the tower appears to have altered to a lesser extent than the north. The historical study has shown that some reliefs in the southern part have been replaced. However, this study does not indicate whether the southern part was originally more altered than the northern section, or whether the southern part has been restored to a greater extent because of its visibility and accessibility to the public.

The mapping in figure 8 shows that the south façade is less degraded than the east tower. Spallings (red zone) are only located on ancient tuffeau. Concerning the degraded parts above the windows, doubt remains about their replacement date. If they had been restored in 1962, they would not be much degraded. They probably were restored in 1853 , but we do not know if original tuffeaux was just re-cut on the surface or replaced with new tuffeau. 


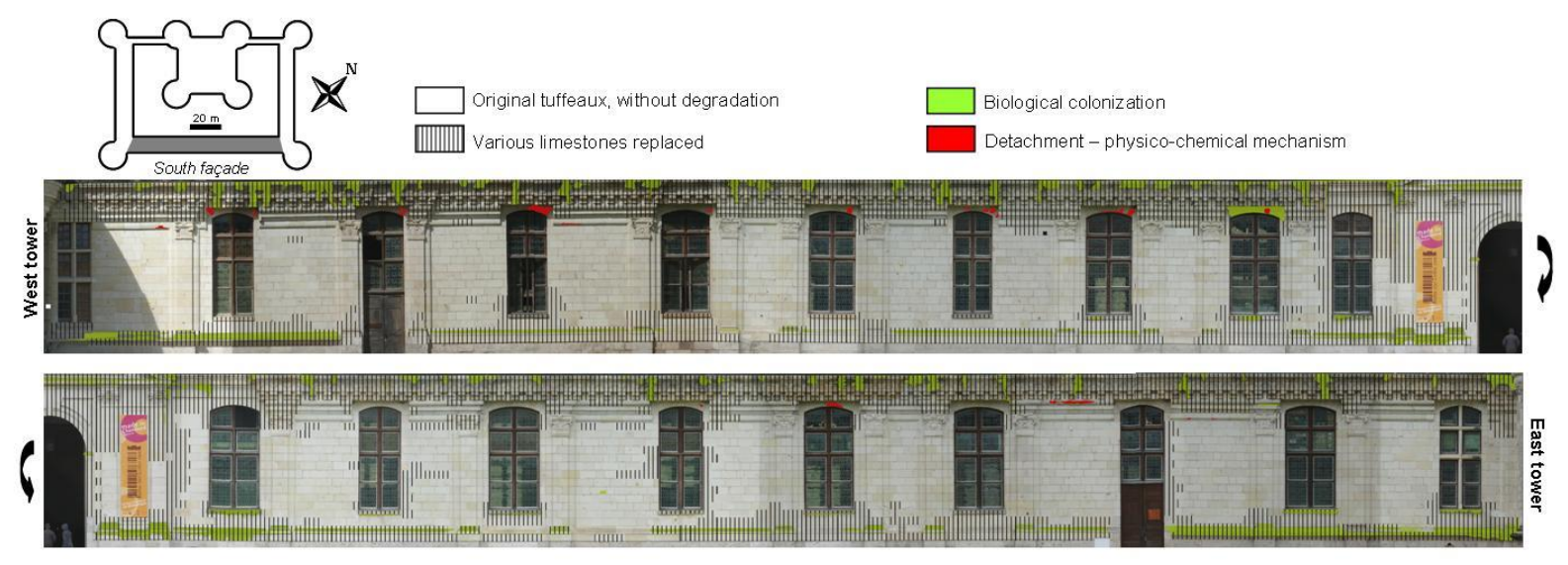

Fig. 8: Age and decay features of stones in the south façade

Visually, in the south façade, spalling are less developed than in the northern parts of the tower, probably because the south facade was restored very often, mostly with Richemont stone (striped zone). Compared to Tuffeau, Richemont stone is more resistant, less porous and so less sensitive to spalling. Moreover, physicochemical degradations are not observed on Richemont stone recently placed in the castle (less than 60 years ago) because it's well known that these types of decay are time dependent. Colonizations (green zone) are less present than on the tower, because of the orientation of the façade (very sunny, like the five center spans of the tower). The development of micro-organisms and then, lichens and mosses, is difficult and slow on a dried wall. But the areas with relief have sometimes biological degradation, because they retain moisture (green zone with superimposition of striped zone).

The damage by detachment progresses very slowly. Indeed, the physical and chemical changes affect older limestone, but not the Richemont stones and tuffeau recently replaced, while the biological alterations affect all kinds of stones and all ages, sometimes with a few years, depending on the orientation of the walls. A physicochemical study of the compatibility between original and replacement stones are necessary to indicate the main parameters which can be considered for the choice of the new stone in order to guarantee the durability of construction.

\section{Conclusions}

A comprehensive folder concerning historical bibliographical and iconographic data was collected regarding Chambord castle and mainly the south façade and the east tower. However, some of the historical documents relating to its construction and restoration are either missing or incomplete. The study of the history of these two relevant parts of castle has shown that the east tower has undergone few restorations since the initial construction of the castle, nearly 500 years ago. The south façade however has often been modified inwardly and outwardly over centuries by different owners. Indeed, almost half of the stones in the south façade have been replaced, as its aesthetic appearance is of great importance for the visitors because it is the main entrance of the castle. So, on the south façade, different limestones (tuffeau and Richemont) coming from different quarries are juxtaposed.

The current state of decay of south façade and the east tower and their history of construction and subsequent restorations provide a basis for understanding the degradation and to propose adapted treatment. It should be noted that, until now, the only solution advocated by the architects and applied is replacement of degraded stones. The study of the façades has revealed different types and states of alteration, with physicochemical or biological origins. The most damaging alteration is spalling: detachment of stone layers of one to three centimetres thickness. The correlation between stone degradation and age indicates that only original stones show spalling or exfoliation. Replacement stones never show this type of degradation, but this statement cannot be directly linked to their less advanced age, because the type of stone used is different. The main replacement stone in the castle of Chambord is the Richemont stone, considered to be more durable and less sensitive to the process causing spalling or exfoliation. No time-related correlation can be made with respect to biological colonisation; this type of degradation is mostly orientation-related.

A study on climatological data at the site has started recently in order to understand the parameters that initiate, trigger and contribute to the development of spalling and exfoliation. Aging tests in controlled 
environmental chambers based on these weather-related data and numerical modelling based on the analysis of these experiments and the physico-chemical characterisation of the damage to the stone are in progress. The mechanisms of spalling are being studied in order to quantify the state of degradation today, in order to predict the evolution of the damage and hence to design a preventive campaign of restoration.

All gathered data concerning Chambord castle: architectural, historical archives and localization of degradations are in progress to construct 3D computer-aided design software to reference all plans and information needed to identify degradation patterns and their correlation with data relative to environmental conditions and history of construction/restoration. This software will be integrated in a digital tool able to simulate degradation propagation and used to evaluate scientifically the appropriateness of restoration/conservation scenarios. Finally, the creation of this unique management tool will provide the basis for the development of the identity and health record of the Chambord castle.

\section{Acknowledgment:}

The authors wish to thank the authority of the Région Centre, in France, for the financial support of the SACRE project. Thanks also to all members of this project, Dashnor Hoxha, Naima Belayachi, Duc Phi Do (PRISME Institut), Jean-Didier Mertz, Mikael Guiavarch, Stephanie Touron (LRMH), Pascal Thévard, Alexandra Fleury, Eric Johannot (Domaine national de Chambord), and Chiara Stefani, Livio de Luca (Map-Gamsau).

\section{References:}

Beck K., Al-Mukhtar M., Rozenbaum O. and Rautureau M., 2003, Characterisation, water transfer properties and deterioration in tuffeau: building material in the Loire valley-France, Int. Journal of Building and Environment, vol. 38, No. 9, 1151-1162

Beck K., Al-Mukhtar M., 2005, Multi-scale characterisation of two French limestones used in historic constructions, Int. Journal of Restoration of Buildings and Monuments, vol. 11, No. 4, 219-226

Beck K., Al-Mukhtar M., 2010, Weathering effects in an urban environment: a case study of tuffeau, a French porous limestone, Geological Society, London, Special publication 2010, vol. 331, 103-111

Birginie J.-M., Auger F., Rivas Brea T., 2000, Changes in the permeability to gas of calcareous stone core samples exposed to salt spray, Materials and Structures, vol. 33, 331-337

Brunet-Imbault B., 1999. Etude des patines de pierres calcaires mises en œuvre en région Centre. PhD thesis, University of Orléans

Bryant S., Ponsot P., Hofbauer D., Caillou J.-S., 2007, Le château de Chambord (Loir-et-Cher) - Un monument trop (peu) regardé, 4th International Congress of Medieval and Modern Archaeology, Paris, 3-8 september 2007

Châtenet M., 2001, Chambord, Paris, Editions du Patrimoine

Desbois (Father and son), 1894, Notice des travaux de restauration exécutés au château de 1882 à 1894, Paris

Dessandier D., 1995. Etude du milieu poreux et des propriétés de transfert des fluides du tuffeau blanc de Touraine. Application à la durabilité des pierres en œuvre. PhD thesis, University of Tours

Dessandier D., 2000, Guide méthodologique des monuments en termes de durabilité et compatibilité, in collaboration with Auger P., Haas H. and Hugues G., BRGM Report

Gorget C., 1990, Carrières et carriers d'Apremont-sur-Allier-sur-Allier (XVII ${ }^{\mathrm{C}}$ XVIII ${ }^{\mathrm{e}}$ siècles), Cahiers d'Archéologie et d'Histoire du Berry, No.102, 3-16

Lorenz J., 1991, Les pierres du Nivernais, Carrières et constructions en France et dans les pays limitrophes, actes du 115e congrès national des sociétés savantes, Paris, 1991, 411-421.

Martin-Demézil J., 1986, Chambord, Société Française d’Archéologie, Paris

Mussat A., 1991, La rivière et la carrière: l'exemple des pays de la Loire, Congrès: Les chantiers de la Renaissance, Tours ,1983-84, 11-26

Paquet P., 1937, La remise en état des communs du château de Chambord, Monuments historiques de la France, 1937, No.3, 221-225

Penet G., 1963, Les travaux de Jules Hardoin-Mansard à Chambord, mémoires de la société des sciences et lettres de Loir-et-Cher, vol. XXXIV, 7-37

Philippon J., Jeannette D., Lefèvre R.A., 1992. La conservation de la pierre monumentale en France. CNRS press, 51-72

Rautureau M., 2001. Tendre comme la pierre, ouvrage collectif sous la direction de Michel Rautureau. Ed. Conseil régional, Centre \& Université d’Orléans, available online http://www.culture.fr/culture/conservation/fr/biblioth/biblioth.htm 
Thomachot C., 2002. Modifications des propriétés pétrophysiques de grès soumis au gel ou recouverts d'encroûtements noirs vernissés. PhD thesis, University of Strasbourg

Yvard J.-C., 1976. Chronologie et sédimentation des calcaires lacustres du Sud-Ouest du Bassin de Paris dans leur environnement structural, In Norois. No. 92, 529-540.

ICOMOS-ISCS, 2008, Illustrated glossary on stone deterioration patterns, available online

http://international.icomos.org/publications/monuments and sites/15/pdf/Monuments and Sites 15 ISCS GI ossary Stone.pdf 